\title{
PENGARUH DIMENSI KOMPETENSI SUMBER DAYA MANUSIA TERHADAP KINERJA PEGAWAI BALAI KARANTINA IKAN, PENGENDALIAN MUTU DAN KEAMANAN HASIL PERIKANAN MEDAN I
}

\author{
${ }^{1}$ Amiruddin Ritonga, ${ }^{2}$ Humaini Nasution, ${ }^{3}$ Aswiluddin, ${ }^{4}$ Sry Liswati \\ ${ }_{1,2,3,4}$ Universitas Islam Sumatera Utara \\ Iaminuddin.mm@gmail.com, ${ }^{2}$ humaini.nst@gmail.com, ${ }^{3}$ aswiluddin.mm@gmail.com, ${ }^{4}$ sry.liswati@gmail.com
}

\begin{abstract}
The formulation of the problem in this study are: How much influence the knowledge, skills and abilities have on employee performance. This study aims to determine the effect of knowledge, skills and abilities on employee performance. Taking the sample using total sampling technique, the sample of this study amounted to 37 people. Knowledge partially has a positive effect on employee performance; Skills partially have a positive effect on employee performance; Ability partially has a positive effect on employee performance; Knowledge, skills and abilities have a positive and significant impact on employee performance Fish Quarantine Center, Quality Control and Safety of Fishery Products I.
\end{abstract}

Keywords : Knowledge; Skills; Ability; Employee Performance

ABSTRAK : Rumusan masalah dalam penelitian ini adalah : Sebarapa besar pengaruh pengetahuan, keterampilan dan kemampuan terhadap kinerja pegawai. Penelitian ini bertujuan untuk mengetahui pengaruh pengetahuan, keterampilan dan kemampuan terhadap kinerja pegawai. Pengambilan sampel menggunakan teknik total sampling maka sampel penelitian ini berjumlah 37 orang. Pengetahuan secara partial berpengaruh positif terhadap kinerja pegawai; Keterampilan secara partial berpengaruh positif terhadap kinerja pegawai; Kemampuan secara partial berpengaruh positif terhadap kinerja pegawai; Pengetahuan, keterampilan dan kemampuan memiliki pengaruh yang positif dan signifikan terhadap kinerja pegawai Balai Karantina Ikan, Pengendalian Mutu dan Keamanan Hasil Perikanan I.

Kata Kunci : Pengetahuan; Keterampilan; Kemampuan; Kinerja Pegawai

\section{Pendahuluan}

Balai Karantina Ikan, Pengendalian Mutu Dan Keamanan Hasil Perikanan Medan I merupakan suatu organisasi yang memiliki tanggung jawab, tugas dan fungsi untuk melindungi sumberdaya perikanan seluruh wilayah negara kesatuan RI dari serangan hama dan penyakit ikan karantina dan melaksanakan pengendalian mutu - keamanan hasil perikanan. Pelaksanaan tugas dan tanggungjawab tersebut dilaksanakan oleh BKIPM dengan didukung oleh 45 Unit Pelaksana Teknis (UPT) dan 285 satker yang melaksanakan tugas fungsi tindak karantina dipintu pemasukan dan pengeluaran wilayah di beberapa propinsi. Rentang kendali BKIPM dalam mengemban tugas pokok bersifat nasional dan luas.
Berdasarkan kenyataan saat ini, tuntutan masyarakat terhadap peningkatan kualitas pelayanan publik dari pemerintah semakin meningkat. Masyarakat berharap proses pelayanan yang diberikan oleh pemerintah dapat dengan lebih mudah,sederhana, lancar, cepat, tepat, ramah, terdapat kepastian, dan kejelasan prosedur serta persyaratan pelayanan yang memenuhi aturan. Pelayanan publik oleh aparatur pemerintah masih dijumpai kelemahan dan kelamaan. Hal ini ditandai dengan masih adanya berbagai keluhan masyarakat yang disampaikan melalui media massa, sehingga dapat menimbulkan citra yang kurang baik terhadap aparatur pemerintah.

Berkaitan dengan penyelenggaraan pemerintah khususnya pelayanan kepada 
masyarakat senantiasa membawa konsekuensi dalam perangkat sumber daya aparatur yang mempunyai kemampuan, keterampilan serta mampu menghasilkan kinerja yang berkualitas. Tujuan organisasi akan dapat dicapai melalui kinerja yang positif dari pegawainya, sebaliknya organisasi akan menghadapi hambatan dalam pencapaian tujuan manakala kinerja para pegawai tidak efektif dalam arti tidak dapat memenuhi tuntutan pekerjaan yang dinginkan oleh organisasi (dalam Achmad, 2011 : 73).

Oleh karena itu, keberhasilan organisasi sangat dipengaruhi oleh kinerja dari pegawainya. Kinerja pegawai adalah hasil kerja secara kualitas dan kuantitas yang dicapai oleh seorang pegawai dalam melaksanakan tugasnya sesuai dengan tanggung jawab yang diberikan kepadanya (Mangkunegara, 2011: 67). Jadi pendefinisian kinerja mengacu pada hasil kerja yang dicapai oleh individu atau kelompok orang dalam suatu organisasi berdasarkan satuan waktu atau ukuran tertentu.

Kenyataannya saat ini, berdasarkan data sekunder yang penulis dapatkan dari Balai Karantina Ikan, Pengendalian Mutu Dan Keamanan Hasil Perikanan Medan I, terdapat beberapa kategori kinerja pegawai yang berbeda, penulis menemukan indikasi bahwa terjadi penurunan kinerja pegawai di Balai Karantina Ikan, Pengendalian Mutu Dan Keamanan Hasil Perikanan Medan I. Berikut merupakan data yang diperoleh penulis mengenai kategori kinerja pegawai adalah sebagai berikut:

Tabel 1 .Laporan Hasil Penilaian Kinerja Pegawai di Balai Karantina Ikan, Pengendalian Mutu Dan Keamanan Hasil Perikanan Medan I

\begin{tabular}{|c|c|c|c|c|c|c|}
\hline \multirow[b]{2}{*}{ Perilaku kerja } & \multicolumn{3}{|c|}{2018} & \multicolumn{3}{|c|}{2019} \\
\hline & $\begin{array}{c}\text { Bobot } \\
(\%)\end{array}$ & $\begin{array}{c}\text { Nilai } \\
\text { Kinerja }\end{array}$ & $\begin{array}{l}\text { SKor } \\
(\%)\end{array}$ & $\begin{array}{c}\text { Bobot } \\
(\%)\end{array}$ & $\begin{array}{c}\text { Nilai } \\
\text { Kinerja }\end{array}$ & $\begin{array}{c}\text { SKor } \\
(\%)\end{array}$ \\
\hline Kedisiplinan & 10 & 80 & 8 & 10 & 75 & 7,5 \\
\hline Tanggung jawab & 10 & 75 & 7,5 & 10 & 70 & 7 \\
\hline Kerjasama & 10 & 80 & 8 & 10 & 75 & 7,5 \\
\hline Kepemimpinan & 10 & 80 & 8 & 10 & 80 & 8 \\
\hline \multicolumn{7}{|c|}{ Hasil Kerja } \\
\hline Kualitas Kerja & 20 & 80 & 16 & 20 & 75 & 15 \\
\hline Ketepatan Waktu & 20 & 80 & 16 & 20 & 70 & 14 \\
\hline Keterampilan kerja & 20 & 80 & 16 & 20 & 65 & 13 \\
\hline Jumlah & & & 79,5 & & & 72 \\
\hline
\end{tabular}

Sumber : Balai Karantina Ikan, Pengendalian Mutu Dan Keamanan Hasil Perikanan Medan I. 2020

Berdasarkan tabel 1 dapat diketahui bahwa hasil penilaian kinerja pegawai Balai Karantina Ikan, Pengendalian Mutu Dan Keamanan Hasil Perikanan Medan I menunjukkan ada penurunan dalam dua tahun terakhir dari tahun 2018 sampai 2019 dikategori cukup dari tabel 1 standar nilai kinerja pegawai. Dapat dilihat dari total skor hasil kerja pada tahun 2018 sebesar 79,5\% dan pada tahun 2019 turun menjadi 72\%. Tentunya hal ini jauh dari harapan instansi yang menginginkan pegawai memiliki kinerja baik yaitu $100 \%$.

Selain itu berdasarkan hasil wawancara dengan pembimbing instansi terdapat beberapa permasalahan mengenai kinerja pegawai, dapat diketahui dari kurangnya ketelitian pegawai dalam membuat laporanlaporan yang ditugaskan.

Untuk mengetahui tinggi rendahnya kinerja pegawai, perlu dilakukan penilaian kinerja pegawai. Penilaian kinerja pegawai proses melalui mana organisasi-organisasi mengevaluasi atau menilai kinerja pegawai, kegiatan ini dapat memperbaiki aktivitas kerja pegawai. Faktor yang dapat dijadikan standar penilaian kinerja pegawai, yaitu: Kualitas kerja yang meliputi ketepatan, ketelitian, serta keterampilan. Kuantitas kerja meliputi output rutin serta output non rutin (ekstra)

Dalam upaya menciptakan pegawai di lingkungan Balai Karantina Ikan, Pengendalian Mutu Dan Keamanan Hasil Perikanan Medan I yang mempunyai keterampilan secara profesional ternyata masih 
sulit mengingat tingkat pendidikan formal pegawai pada Balai Karantina Ikan, Pengendalian Mutu Dan Keamanan Hasil Perikanan Medan I. Data mengenai tingkat pendidikan formal pegawai Balai Karantina Ikan, Pengendalian Mutu Dan Keamanan Hasil Perikanan Medan I dapat terlihat pada tabel 1.2 dibawah ini:

Tabel 2. Pendidikan Pegawai Balai Karantina

Ikan, Pengendalian Mutu Dan Keamanan Hasil Perikanan Medan I

\begin{tabular}{|c|c|}
\hline Pendidikan & Jumlah pegawai \\
\hline S2 & 5 orang \\
\hline S1 & 18 orang \\
\hline D3 & 9 orang \\
\hline SMA & 11 orang \\
\hline
\end{tabular}

Sumber : Balai Karantina Ikan, Pengendalian Mutu Dan Keamanan Hasil Perikanan Medan I

Berdasarkan tabel 2 diatas, tabel ini menyangkut keterampilan pegawai, terlihat bahwa lulusan terbanyak dari pegawai Balai Karantina Ikan, Pengendalian Mutu Dan Keamanan Hasil Perikanan Medan I adalah S1 yaitu sebanyak 18 orang. Sedangkan tamatan S2 merupakan lulusan paling sedikit 5 orang. Pegawai yang lulusan D3 sebanyak 9 orang dan Pegawai yang lulusan SMA sebanyak 11 orang. Hal ini dapat dilihat bahwa pegawai rata-rata memiliki keterampilan yang kurang baik jika dilihat dari lulusan pegawai. Mengenai keadaan Balai Karantina Ikan, Pengendalian Mutu Dan Keamanan Hasil Perikanan Medan I seharusnya pegawai dengan keterampilan yang dimiliki mampu menyelesaikan tugas dengan baik, tetapi kenyataannya pegawai Balai Karantina Ikan, Pengendalian Mutu Dan Keamanan Hasil Perikanan Medan I dalam pengerjaan tugas masih banyak yang keliru serta pelayanan yang lamban.

Uraian di atas terihat bahwa kinerja pegawai masih kurang maksimal dalam beberapa hal, kemungkinan hal tersebut disebabkan oleh beberapa faktor dari diri pegawai itu sendiri. Adanya kesenjangan antara kemampuan yang dimiliki pegawai dengan yang dikehendaki organisasi menyebabkan perlunya suatu instansi menjembatani kesenjangan tersebut, salah satu caranya adalah dengan melakukan penilaian kepada pegawai tersebut sehingga diharapkan diketahui faktor apa saja yang menjadikan kesenjangan serta mencari solusi terhadap faktor yang menjadikan kemampuan dan kinerja pegawai meningkat serta diharapkan kesalahan dalam kerja akan berkurang.

Selain tingkat pendidikan formal, keterampilan pegawai juga dapat kita lihat dari keikutsertaan mereka dalam pendidikan non formal/pelatihan (pendidikan dan pelatihan). Berdasarkan hasil pengamatan penulis menujukkan bahwa pegawai yang pernah mengikuti program pendidikan dan pelatihan hanya sekitar 50\% saja. Data ini telah memberikan gambaran bahwa hanya sebagian saja pegawai yang pernah mengikuti program pendidikan dan pelatihan, sementara tuntutan pekerjaan mengharuskan seluruh pegawai untuk mengikuti program pendidikan dan pelatihan sesuai dengan bidang tugas masing-masing. Program program semacam itu sudah menjadi kebutuhan para pegawai dalam rangka meningkatkan dan keterampilannya.

Dalam meningkatkan kinerja pegawai membutuhkan kemampuan fisik dan kemampuan berfikir yang tinggi, namun demikian kenyataan dilapangan menunjukkan bahwa tingkat kemampuan fisik pegawai di Balai Karantina Ikan, Pengendalian Mutu Dan Keamanan Hasil Perikanan Medan I tergolong masih rendah. Hal ini dapat kita lihat pada tingkat absensi pegawai pada Balai Karantina Ikan, Pengendalian Mutu Dan Keamanan Hasil Perikanan Medan I dapat di gambarkan bahwa kemampuan fisik masih rendah, belum sesuai dengan yang diharapkan. Terbukti dengan hasil wawancara kepada Kepala Bidang Kepegawaian beliau mengatakan masih banyak pegawai yang tingkat absensinya masih tinggi sekitar $45 \%$ dalam kurun waktu 3 bulan terakhir hal ini juga sering terlihat pegawai bolos pada jam masuk kantor, datang dan keluar kantor sebelum waktunya, lebih sering berkumpul di kantin di banding berada di ruang kerja.

Kurang optimalnya kinerja pegawai pada Balai Karantina Ikan, Pengendalian Mutu Dan Keamanan Hasil Perikanan Medan I di akibatkan oleh kemampuan fisik yang kurang mendukung terlihat dari ketidakhadiran pegawai. Sehingga beberapa pekerjaan tidak dikerjakan sesuai dengan waktu yang telah di tentukan. Kondisi tersebut menimbulkan permasalahan dalam pencapaian kinerja pada Balai Karantina Ikan, Pengendalian Mutu Dan Keamanan Hasil 
Perikanan Medan I. Pencapaian kinerja yang belum optimal diduga karena kurangnya pengetahuan, keterampilan dan kemampuan yang kurang baik.

\subsection{Rumusan Masalah}

Setiap instansi pasti mempunyai masalah yang berbeda-beda dengan instansi lainnya. Adanya perubahan yang selalu dihadapi oleh setiap instansi baik yang berada diluar maupun didalam instansi tersebut dapat menjadi hambatan demi pencapaian tujuan yang efektif dan efisien.

Bedasarkan latar belakang masalah tersebut diatas, maka yang menjadi rumusan masalah dalam penelitian ini adalah :

a. Seberapa besar pengaruh pengetahuan terhadap kinerja pegawai Balai Karantina Ikan, Pengendalian Mutu Dan Keamanan Hasil Perikanan Medan I

b. Seberapa besar pengaruh keterampilan terahadap kinerja pegawai Balai Karantina Ikan, Pengendalian Mutu Dan Keamanan Hasil Perikanan Medan I

c. Sebarapa besar pengaruh kemampuan terhadap kinerja pegawai Balai Karantina Ikan, Pengendalian Mutu Dan Keamanan Hasil Perikanan Medan I

d. Sebarapa besar pengaruh pengetahuan, keterampilan dan kemampuan terhadap kinerja pegawai Balai Karantina Ikan, Pengendalian Mutu Dan Keamanan Hasil Perikanan Medan I

\subsection{Batasan Masalah}

Agar permasalahan yang dikaji terarah maka permasalahan dibatasi sebagai berikut. Penelitian ini hanya membahas faktor pengaruh dimensi kompetensi sumber daya manusia terhadap kinerja pegawai Balai Karantina Ikan, Pengendalian Mutu Dan Keamanan Hasil Perikanan Medan I.

\subsection{Hioptesis}

Berdasarkan kerangka pemikiran diatas maka hipotesis penelitian adalah sebagai berikut:

a. Secara parsial terdapat pengaruh hubungan positif dan signifikan pengetahuan terhadap kinerja pegawai

b. Secara parsial terdapat pengaruh hubungan positif dan signifikan keterampilan terhadap kinerja pegawai c. Secara parsial terdapat pengaruh hubungnan positif dan signifikan kemampuan terhadap kinerja pegawai

d. Secara simultan terdapat pengaruh hubungan positif dan signifikan pengetahuan, keterampilan dan kemampuan terhadap kinerja pegawai.

\subsection{Tujuan Penelitian}

Berkaitan dengan masalah yang disebutkan di atas, maka tujuan dari penelitian ini adalah sebagai berikut: :

a. Untuk mengetahui besarnya pengaruh pengetahuan terhadap kinerja pegawai Balai Karantina Ikan, Pengendalian Mutu Dan Keamanan Hasil Perikanan Medan I

b. Untuk mengetahui besarnya pengaruh keterampilan terahadap kinerja pegawai Balai Karantina Ikan, Pengendalian Mutu Dan Keamanan Hasil Perikanan Medan I

c. Untuk mengetahui besarnya pengaruh kemampuan terhadap kinerja pegawai Balai Karantina Ikan, Pengendalian Mutu Dan Keamanan Hasil Perikanan Medan I

d. Untuk mengetahui besarnya pengaruh pengetahuan, keterampilan dan kemampuan terhadap kinerja pegawai Balai Karantina Ikan, Pengendalian Mutu Dan Keamanan Hasil Perikanan Medan I

\section{Metode Penelitian \\ 2.1. Populasi}

Populasi adalah sekumpulan objek yang menjadi pusat perhatian, yang padanya terkandung informasi yang ingin diketahui. Objek ini disebut dengan satuan analisis. Satuan analisis ini memiliki kesamaan perilaku atau karakteristik yang ingin diteliti. Menurut Arikunto (2013: 173) populasi adalah keseluruhan dari subjek penelitian. Jadi yang dimaksud populasi adalah individu yang memiliki sifat yang sama walaupun prosentase kesamaan itu sedikit, atau dengan kata lain seluruh individu yang akan dijadikan sebagai obyek penelitian..

Maka yang menjadi populasi dalam penelitian ini adalah seluruh pegawai yang ada di Balai Karantina Ikan, Pengendalian Mutu Dan Keamanan Hasil Perikanan Medan I yang berjumlah 39 orang dengan rincian sebagai berikut: 
Tabel 3. Kerangka Populasi

\begin{tabular}{|r|l|c|}
\hline No & Jabatan & Jumlah \\
\hline 1 & Kepala Balai & 1 \\
\hline 2 & Kepala seksi & 2 \\
\hline 3 & PHPI & 22 \\
\hline 4 & Kepala Sub- Bagian & 1 \\
& TU & 1 \\
\hline 5 & Pengawas & 6 \\
\hline 6 & Analis & 1 \\
\hline 7 & Penyusun & 2 \\
\hline 8 & Pranata & 1 \\
\hline 9 & Bendahara & 2 \\
\hline 10 & Pengadministrasi & $\mathbf{3 9}$ \\
\hline & Total &
\end{tabular}

Sumber: Balai Karantina Ikan, Pengendalian Mutu Dan Keamanan Hasil Perikanan Medan I -2020

\subsection{Sampel}

Sampel merupakan contoh atau himpunan bagian (subset) dari suatu populasi yang dianggap mewakili populasi tersebut sehingga informasi apa pun yang dihasilkan oleh sampel ini bisa dianggap mewakili keseluruhan populasi. Arikunto (2013: 174) berpendapat bahwa sampel adalah sebagian atau wakil populasi yang diteliti. Teknik pengambilan sampel adalah berbagai cara yang ditempuh untuk pengambilan sampel agar mendapatkan sampel yang benar-benar sesuai dengan seluruh subjek penelitian tersebut (Nursalam, 2013: 113).

Mengingat keterbatasan jumlah populasi pada objek peneltian. Teknik pengambilan sampel pada penelitian ini adalah total sampling. Total sampling adalah teknik pengambilan sampel dimana jumlah sampel sama dengan populasi (Sugiyono, 2013: 76). Alasan mengambil total sampling karena menurut Sugiyono (2013: 77) jumlah populasi yang kurang dari 100, seluruh populasi dijadikan sampel penelitian semuanya.

Berkaitan dengan judul penelitian yang diambil, maka sampel dalam penelitian ini adalah seluruh yang ada di Balai Karantina Ikan, Pengendalian Mutu Dan Keamanan Hasil Perikanan Medan I yang berjumlah 37 orang ( 2 orang dari populasi tidak dijadikan sampel yaitu Kepala Balai dan penelliti sebagai Analis Keuangan ) dengan rincian sebagai berikut:

\begin{tabular}{|r|l|c|c|c|}
\hline No & Jabatan & Populasi & Sampel & Keterangan \\
\hline 1 & Kepala Balai & 1 & - & Tidak diteliti \\
\hline 2 & Kepala seksi & 2 & 2 & Diteliti \\
\hline 3 & PHPI & 22 & 22 & Diteliti \\
\hline 4 & Kepala Sub- Bagian TU & 1 & 1 & Diteliti \\
\hline 5 & Pengawas & 1 & 1 & Diteliti \\
\hline 6 & Analis & 6 & 5 & 1 Peneliti \\
\hline 7 & Penyusun & 1 & 1 & Diteliti \\
\hline 8 & Pranata & 2 & 2 & Diteliti \\
\hline 9 & Bendahara & 1 & 1 & Diteliti \\
\hline 10 & Pengadministrasi & 2 & 2 & Diteliti \\
\hline & Total & $\mathbf{3 9}$ & $\mathbf{3 7}$ & \\
\hline
\end{tabular}

Sumber: Balai Karantina Ikan, Pengendalian Mutu Dan Keamanan Hasil Perikanan Medan I -2020

\subsection{Uji Normalitas}

Pengujian normalitas data bertujuan untuk melihat normal tidaknya sebaran data yang akan dianalisis. Model regresi yang baik adalah distribusi normal atau mendekati normal. Untuk melihat normalitas data ini digunakan pendekatan grafik yaitu Normality Probability Plot.

Deteksi normalitas dengan melihat penyebaran data (titik) pada sumbu diagonal dari grafik. Menurut Santoso (2014:214), dasar pengambilan keputusan adalah: a. Jika data menyebar disekitar garis diagonal dan mengikuti arah garis diagonal, maka model regresi memenuhi asumsi normalitas.

b. Jika data menyebar jauh dari garis diagonal dan atau tidak mengikuti arah garis diagonal, maka model regresi tidak memenuhi asumsi normalitas. Pada output SPSS versi 24.00 bagian normal $P$-P Plot of Regresion

Standardized Residual, dapat dijelaskan bahwa data-data (titik-titik) cenderung lurus 
mengikuti garis diagonal sehingga data dalam penelitian ini cenderung berdistribusi normal, seperti terlihat pada gambar dibawah ini.

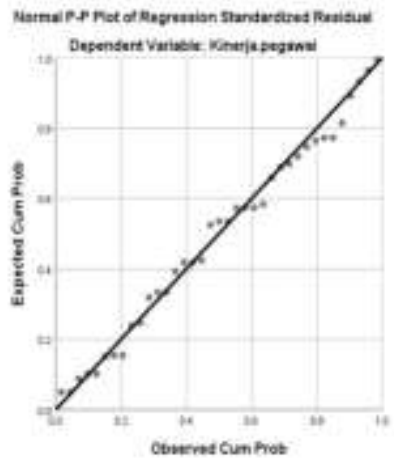

Gambar 2. Normalitas Data

\subsection{Uji Multikolinearitas}

Pengujian multikolinearitas dilakukan untuk melihat apakah pada model regresi ditemukan adanya korelasi antara variabel bebas. Jika terjadi korelasi, maka dinamakan terdapat problem multikolinearitas. Cara mendeteksinya adalah dengan melihat nilai Variance Inflation Factor (VIF). Menurut Santoso (2014:203), pada umumnya jika VIF lebih besar dari 5, maka variabel bebas tersebut mempunyai persoalan multikolinearitas dengan variabel bebas lainnya.

Pada ouput SPSS bagian Coefficient, semua angka VIF berada dibawah 5, hal ini menunjukan tidak terjadi multikolinearitas, seperti dapat dilihat pada tabel dibawah ini.

Tabel 5. Uji Multikolinearitas Collinearity Statistics

\begin{tabular}{|ll|rr|}
\hline \multicolumn{1}{|l|}{ Model } & Tolerance & VIF \\
\hline $1 \quad$ (Constant) & & \\
\cline { 2 - 4 } Pengetahuan & .798 & 1.254 \\
\cline { 2 - 3 } Keterampilan & .734 & 1.363 \\
\hline Kemampuan & .644 & 1.552 \\
\hline \multicolumn{3}{|c|}{ a. Dependent Variable: }
\end{tabular}

kinerja.pegawai

\subsection{Uji Heteroskedastisitas}

Pengujian heteroskedastisitas bertujuan untuk melihat apakah dalam sebuah model regresi terjadi ketidaksamaan varians dari residual yang merupakan suatu pengamatan ke pengamatan yang lainnya. Jika varians dari residual yang merupakan suatu pengamatan ke pengamatan yang lain bernilai tetap, maka hasil data disebut homoskedastisitas dan jika varians berbeda atau bernilai tidak tetap maka disebut heteroskedastisitas. Model regresi yang baik adalah model yang bernilai tetap atau homoskedastisitas atau tidak terjadi heteroskedastisitas.

Deteksi heteroskedastisitas dilakukan dengan cara melihat ada tidaknya pola tertentu pada data yang diolah. Menurut Santoso (2014:208), dasar pengambilan keputusannya adalah:

a. Jika pola tertentu seperti titik-titik yang ada membentuk suatu pola tertentu yang teratur, maka terdapat situasi heteroskedastisitas.

b. Jika tidak ada pola yang jelas, serta titiktitik menyebar diatas dan dibawah angka nol pada sumbu Y, maka tidak terjadi heteroskedastisitas.

Pada output SPSS dibagian Scatrerplot, terlihat titk-titik menyebar secara acak, tidak membentuk sebuah pola tertentu yang jelas, serta tersebar baik diatas maupun dibawah angka nol pada sumbu Y. Hal ini berarti tidak terjadi heterskedastisitas pada model regresi, sehingga model regresi layak dipakai. Pola Scatterplot dapat dilihat pada gambar dibawah ini.

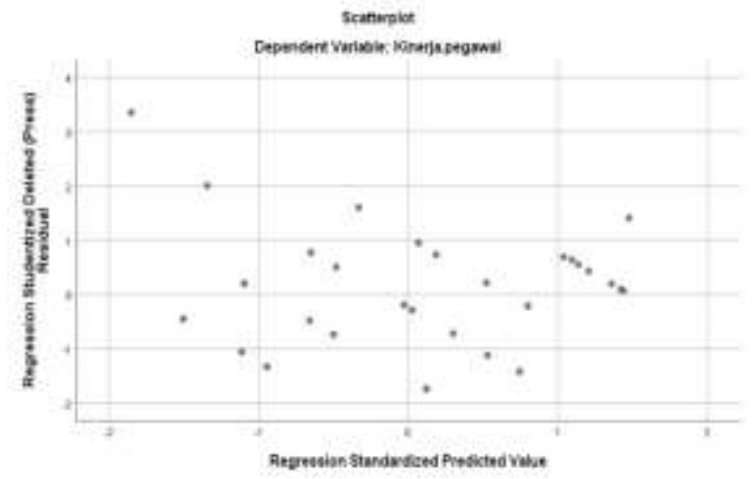

Gambar 2. Uji Heteroskedastitas

\section{Evaluasi Data (Analisa Regresi Linier Berganda ) \\ 3.1 Pengujian Hipotesis}

Dalam evaluasi data ini penulis akan melakukan pengujian hipotesis, baik secara partial ataupun secara simultan. Selanjutnya untuk mempermudah dalam evaluasi data ini, maka penulis mencari niali-nilai yang dibutuhkan dengan menggunakan perangkat lunak komputer yaitu program SPSS V.24.00 for windows dengan hasil data sebagai berikut: 
Tabel 6. Hasil Uji Statistik Keofesien Regresi

\begin{tabular}{|l|r|r|r|r|r|}
\hline \multirow{2}{*}{ Model } & \multicolumn{2}{|c|}{$\begin{array}{c}\text { Unstandardized } \\
\text { Coefficients }\end{array}$} & $\begin{array}{l}\text { Standardized } \\
\text { Coefficients }\end{array}$ & \multirow{2}{*}{$\mathrm{t}$} & \multirow{2}{*}{ Sig. } \\
\cline { 2 - 5 } & \multicolumn{1}{|c|}{ B } & Std. Error & \multicolumn{1}{c|}{ Beta } & & \\
\hline \multirow{2}{*}{ (Constant) } & 1.139 & 4.998 & & .228 & .821 \\
1 & .478 & .109 & .458 & 4.376 & .000 \\
Pengetahuan & .272 & .091 & .326 & 2.992 & .005 \\
Keterampilan & .283 & .110 & .298 & 2.564 & .015 \\
\hline
\end{tabular}

a. Dependent Variable: kinerja pegawai

Berdasarkan tabel 5.12 diatas dapat dibuat persamaan regresi sebagai berikut: $\mathrm{Y}=\mathrm{a}+$ $\mathrm{b} 1 \mathrm{X} 1+\mathrm{b} 2 \mathrm{X} 2+\mathrm{b} 3 \mathrm{X} 3+\varepsilon$

$$
\begin{aligned}
& Y=1,139+0,478 X_{1}+0,272 X_{2}+ \\
& 0,283 X_{3}+\varepsilon
\end{aligned}
$$

Persamaan diatas dijelaskan bahwa koefesien pengetahuan mempunyai nilai positif yaitu 0,478 , hal ini menunujukan bahwa variabel pengetahuan mempunyai pengaruh positif terhadap kinerja pegawai.

Berdasarkan persamaan diatas bahwa koefesien keterampilan memiliki nilai positif yaitu 0,272. Hal ini menunjukan bahwa variabel keterampilan mempunyai pengaruh positif terhadap kinerja pegawai.

Berdasarkan persamaan diatas bahwa koefesien kemampuan juga memiliki nilai positif yaitu 0,283 . Hal ini menunjukan bahwa variabel kemampuan juga mempunyai pengaruh positif terhadap kinerja pegawai.

Dengan demikian bila dimensi dari kompetensi sumber daya manusia yang meliputi pengetahuan, keterampilan dan kemampuan dapat di laksanakan dengan baik dan maksimal akan berdampak positif terhadap kinerja pegawai pada Balai Karantina Ikan, Pengendalian Mutu Dan Keamanan Hasil Perikanan Medan I.

\subsection{Pengujian Secara Simultan (Uji F)}

Untuk melihat hasil dari pengujian secara simultan anara variabel pengetahuan, keterampilan dan kemampuan terhadap kinerja pegawai pada Balai Karantina Ikan, Pengendalian Mutu Dan Keamanan Hasil Perikanan Medan I dapat di jelaskan pada tabel di bawah ini :

\begin{tabular}{|c|c|c|c|c|c|c|}
\hline \multicolumn{2}{|c|}{ Model } & Sum of squares & $\mathrm{df}$ & Mean Square & $\mathrm{F}$ & Sig. \\
\hline \multirow{3}{*}{1} & Regression & 53.904 & 3 & 17.968 & 27.234 & $.000^{\mathrm{b}}$ \\
\hline & Residual & 21.772 & 33 & .660 & & \\
\hline & Total & 75.676 & 36 & & & \\
\hline
\end{tabular}

Tabel 7. Hasil Uji Statistik Secara Simultan

a. Dependent Variable: Kinerja.pegawai

b. Predictors: (Constant), Kemampuan, Pengetahuan, Keterampilan

Pada tabel 7 diatas terlihat bahwa nilai pengetahuan, keterampilan dan kemampuan Fhitung adalah 27,234 dan nilai signifikansi memiliki pengaruh yang positif dan signifikan 0,000. Diketahui nilai $F_{\text {tabel }}$ dengan tingkat terhadap kinerja pegawai pada Balai Karantina kepercayaan 95\% ( $\alpha$ :0,05) adalah 2,840. Ikan, Pengendalian Mutu Dan Keamanan Hasil Oleh karena itu nilai Fhitung $>$ Ftabel $(27,538$ $>$ 2,840) maka $\mathrm{H}_{\mathrm{O}}$ ditolak dan menerima hipotesis dalam penelitian ini yaitu bahwa

Perikanan Medan I.

\subsection{Pengujian Secara Parsial (Uji t)}

\begin{tabular}{|c|c|c|c|c|c|c|}
\hline \multirow{2}{*}{\multicolumn{2}{|c|}{ Model }} & \multicolumn{2}{|c|}{ Unstandardized Coefficients } & Standardized Coefficients & \multirow[t]{2}{*}{$\mathrm{t}$} & \multirow[t]{2}{*}{ Sig. } \\
\hline & & B & Std. Error & Beta & & \\
\hline \multirow{4}{*}{1} & (Constant) & 1.139 & 4.998 & & .228 & .821 \\
\hline & Pengetahuan & .478 & .109 & .45 & 4.376 & .000 \\
\hline & Keterampilan & .272 & .091 & .32 & 2.992 & .005 \\
\hline & Kemampuan & .283 & .110 & .29 & 2.564 & .015 \\
\hline
\end{tabular}

Tabel 8. Hasil Uji Parsial Variabel X Terhadap Y

a. Dependent Variable: kinerja pegawai 


\subsubsection{Pengaruh Pengetahuan Terhadap Kinerja Pegawai}

Untuk mengetahui secara partial pengaruh pengetahuan terhadap kinerja pegawai dapat dilihat pada tebel 8 diatas. Berdasarkan tabel tersebut diperoleh nilai thitung sebesar 4,376 dan nilai signifikansi 0,000 . Sedangkan nilai ttabel pada tingkat kepercayaan 95\% ( $\alpha$ : $0,05)$ adalah 2,021. Dengan demikian nilai thitung > tabel $(4,376>2,021)$ maka $\mathrm{H}_{\mathrm{O}}$ ditolak dan menerima hipotesis dalam penelitian ini yaitu pengetahuan secara partial berpengaruh positif terhadap kinerja pegawai Balai Karantina Ikan, Pengendalian Mutu Dan Keamanan Hasil Perikanan Medan I.

\subsubsection{Pengaruh Keterampilan Terhadap Kinerja Pegawai}

Untuk mengetahui secara partial pengaruh keterampilan terhadap kinerja pegawai, dapat dilihat pada tebel 8 diatas. Berdasarkan tabel tersebut diperoleh nilai thitung sebesar 2,992 dan nilai signifikansi 0,052 . Sedangkan nilai ttabel pada tingkat kepercayaan 95\% ( $\alpha$ : $0,05)$ adalah 2,021. Dengan demikian nilai thitung > tabel $(2,992>2,021)$ maka $\mathrm{H}_{\mathrm{O}}$ ditolak dan menerima hipotesis dalam penelitian ini yaitu keterampilan secara partial berpengaruh positif terhadap kinerja pegawai
Balai Karantina Ikan, Pengendalian Mutu Dan Keamanan Hasil Perikanan Medan I.

\subsubsection{Pengaruh Kemampuan Terhadap Kinerja Pegawai}

Untuk mengetahui secara partial pengaruh kemampuan terhadap kinerja pegawai, dapat dilihat pada tebel 8 diatas. Berdasarkan tabel tersebut diperoleh nilai thitung sebesar 2,564 dan nilai signifikansi 0,015 . Sedangkan nilai tabel pada tingkat kepercayaan $95 \%(\alpha: 0,05)$ adalah 2,021. Dengan demikian nilai thitung $>$ tabel ( 2,564 > 2,021 ) maka $\mathrm{H}_{\mathrm{O}}$ ditolak dan menerima hipotesis dalam penelitian ini yaitu kemampuan secara partial berpengaruh positif terhadap kinerja pegawai Balai Karantina Ikan, Pengendalian Mutu Dan Keamanan Hasil Perikanan Medan I.

\subsection{Uji Koefisien Determinasi $\left(\mathbf{R}^{2}\right)$}

Tujuan dari uji determinan adalah untuk mengetahui seberapa besar pengaruh variabel independent terhadap variabel dependent. Guna melihat hasil uji determinan maka dapat diketahui nili $\mathrm{R}$ Square atau koefesien determinasi dan dapat dilihat pada tabel 9 dibawah ini.

Tabel 9. Model Summary

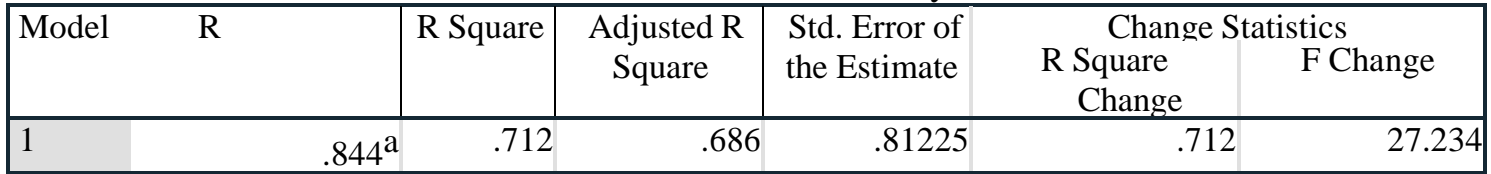

a. Predictors: (Constant), Kemampuan, Pengetahuan, Keterampilan

b. Dependent Variable: Kinerja.pegawai

Nilai R Square pada tabel 9. diatas adalah 0,712 . Hal ini menunjukan bahwa $71,20 \%$ variabel kinerja pegawai Balai Karantina Ikan, Pengendalian Mutu Dan Keamanan Hasil Perikanan Medan I dapat dijelaskan oleh variabel kemampuan, pengetahuan dan keterampilan dan sisanya sebesar 28,80\% di jelaskan oleh variabel lain yang tidak ikut diteliti pada penelitian ini.

\section{Kesimpulan}

a. Pengetahuan secara partial berpengaruh positif terhadap kinerja pegawai Balai Karantina Ikan, Pengendalian Mutu Dan Keamanan Hasil Perikanan Medan I

b. Keterampilan secara partial berpengaruh positif terhadap kinerja pegawai Balai
Karantina Ikan, Pengendalian Mutu Dan Keamanan Hasil Perikanan Medan I

c. Kemampuan secara partial berpengaruh positif terhadap kinerja pegawai Balai Karantina Ikan, Pengendalian Mutu Dan Keamanan Hasil Perikanan Medan I

d. Pengetahuan, keterampilan dan kemampuan memiliki pengaruh yang positif dan signifikan terhadap kinerja pegawai pada Balai Karantina Ikan, Pengendalian Mutu Dan Keamanan Hasil Perikanan Medan I

e. Dengan nilai $\mathrm{R}$ Square 0,712. Hal ini menunjukan bahwa $71,20 \%$ variabel kinerja pegawai dapat dijelaskan oleh variabel kemampuan, pengetahuan dan keterampilan dan sisanya sebesar $28,80 \%$ 
di jelaskan oleh variabel lain yang tidak ikut diteliti.

\section{DAFTAR PUSTAKA}

Achmad, S. 2011. Sistem Manajemen Kinerja. Jakarta: Bumi Aksara. Amirullah. 2015. Pengantar Manajemen. Jakarta: Mitra Wacana Media.

Ardiana, Brahmayanti, Subaedi. 2010 Kompetensi Sumber Daya Manusia UKM terhadap Kinerja UKM. Tesis.

Arikunto, Suharsimi. 2013. Prosedur Penelitian Suatu Pendekatan Praktek. Jakarta: Rineka Cipta.

Bangun, Wilson. 2012. Manajemen Sumber Daya Manusia. Jakarta: PT Gelora Aksara Pratama.

Dessler, Gary. 2010. Manajemen Sumber Daya Manusia. Jakarta: Salemba Empat.

Endang Sulistyaningsih, \& Yudo Swasono. 2010. Pengembangan Sumber Daya Manusia. Jakarta : Cv. Izufa Gempita.

Ghozali, Imam. 2016. Aplikasi Analisis Multivariate dengan SPSS. Semarang: Badan Penerbit UNDIP.

Gibson, James L, et. all. 2011. Organisasi: Berilaku, Struktur, Proses. Alih bahasa : Djarkasih. Jakarta: Erlangga. , 2013. Manajemen Sumber Daya Manusia. Alih bahasa : Djarkasih. Jakarta: Erlangga.

Heny Sidanti. 2015. Pengaruh lingkungan kerja, disiplin kerja dan motivasi kerja terhadap kinerja pegawai negeri sipil di koperasi pegawai republik Indonesia (kpri) ikatan membangun bahagia sejahtera jambon ponorogo. Jurnal.

Hutajulu, Herlina. 2011. Pengaruh kemampuan kerja pegawai terhadap kinerja pegawai puskesmas Pembantu S.M Rejo, Binjai. Skripsi, FE USU, Medan.

Hutapea, Parulian dan Nuriana Thoha. 2010. Kompetensi Komunikasi Plus: Teori, Desain, Kasus dan Penerapan Untuk HR dan Organisasi yang Dinamis. Jakarta: Gramedia Pustaka Utama.

Kristiani. 2013. Pengaruh Kemampuan Kerja, Kompensasi dan Motivasi Kerja Terhadap Prestasi kerja Karyawan Studi Pada Karyawan
Operator PT. Indonesia Power Unit Bisnis Pembangkitan. Jurnal.

Mangkunegara, A.P., 2011. Manajemen Sumber Daya Manusia

Perusahaan. Bandung: Remaja Rosdakarya. 2012. Evaluasi Kinerja Sumber Daya Manusia. Bandung: Remaja Rosdakarya.

2014. Perencanaan dan Pengembangan Sumber Daya Manusia. Bandung: Remaja Rosdakarya.

Moenir. 2012. Transformasi Pelayanan Umum di Indonesia. Jakarta: PT. Bumi Aksara.

Notoatmodjo, Soekidjo. 2012. Pengembangan Sumber Daya Manusia. Jakarta: Rineka Cipta.

Nursalam. 2013. Manajemen Keperawatan: Aplikasi dalam praktik keperawatan professional. (Edisi 3). Jakarta: Salemba Medika.

Prabu, Sanjaya. 2013. Manajemen Sumber daya Manusia. Bandung: Rineka Cipta. Ramadhani, Arif. 2011. Etos Kerja. Jakarta:Warta Bukaka.

Reinhard Efraim Murbijanto. 2013. Analisis Pengaruh Kompetensi Kerja dan Lingkungan Fisik terhadap Kinerja Pegawai (Studi Pada Pegawai Dinas Tenaga Kerja Kabupaten Bekasi). Jurnal.

Riva'i, Veithzal. 2011. Kepemimpinan dan Perilaku Organisasi. Jakarta: PT. Raja Grafindo Persada.

Rizal et al. 2010. Pengaruh Faktor Kompetensi terhadap Kinerja Individu di Instansi Agroindustri Go Public Jakarta. Jurnal.

Robbins, Stephen P. dan Judge. 2011. Manajemen Sumber daya Manusia. Jakarta: Salemba Empat. , 2012. Perilaku Organisasi, Jilid 2. Jakarta: Salemba Empat. Ruky, Achmad S. 2013. Sistem Manajemen Kinerja. Jakarta: Bumi Aksara.

Siagian, Sondang P. 2010. Teori dan Praktek Kepemimpinan. Jakarta: CV Haji Mas Agung.

Sudarmanto. 2012. Manajemen Sumber Daya Manusia. Yogyakarta: Pustaka Pelajar.

Pengembangan Yogyakarta: Pustaka Pelajar. 
2014. Kinerja dan

Pengembangan Kompetensi SDM.

Yogyakarta: Pustaka Pelajar.

Sugiyono. 2013. Metode Penelitian

Bisnis, Cetakan kesembilan. Bandung:

Alfabeta.

, $2017 . \quad$ Metode

Penelitian Pendidikan Pendekatan

Kualitatif, Kuantitatif dan $\mathbf{R} \&$ D.

Bandung: Alfabeta.

Sutrisno, Eddy. 2011. Manajemen Sumber

Daya Manusia. Jakarta: Kencana.

Suwatno dan Priansa, Doni. 2013.

Manajemen Sumber Daya Manusia dan Organisasi Publik dan Bisnis. Bandung : Alfabeta.

Suwatno. 2012. Azas-Azas Manajemen Sumber Daya Manusia. Bandung: Suci Press.

Tati Setiawati, 2009. Pengaruh Kompetensi Kerja terhadap Kinerja Dosen (Studi Kasus Di FPTK UPI). Jurnal.

Taufik, Rachim. 2011. Pengaruh Komunikasi, Motivasi dan Kepemimpinan Terhadap Kinerja Karyawan di PT. Bober Bandung. Jurnal.

Triton, PB. 2013. Manajemen Sumber Daya Manusia: Perspektif Partnership dan Kolektivitas. Yogyakarta: Tugu.

Wahyuningrum, 2013. Hubungan Kemampuan, Kepuasan dan Disiplin Kerja dengan Kinerja Pegawai di Kecematan Tanggungharjo Kabupaten Grobogan, Program Pascasarjana Universitas Diponegoro. Tesis Program Studi : Magister .

Wati, L. A., \& Primyastanto, M. 2015. Ekonomi Produksi Perikanan dan Kelautan Modern Teori dan Aplikasinya. Jakarta: UI Pers.

Wibowo. 2012. Manajemen Kinerja. Jakarta: PT. Raja Grafindo Persada. Wirawan. 2015. Manajemen Sumber Daya Manusia Indonesia. Jakarta.

Penerbit: Salemba Empat.

Yuniarsih, Tjutju \& Suwatno. 2012. Manajemen Sumber Daya Manusia, Teori, Aplikasi dan Isu Penelitian. Bandung: Alfabeta. 2013. Manajemen Sumber Daya

Manusia. Bandung: Alfabeta. 